\title{
KNOWLEDGE AND INTERPRETATION PROCESSES OF THE ANDALUSÍ BATH OF EL NOGAL OR BAÑUELO (HAMMĀM AL-ŶYWZA) IN GRANADA, SPAIN (1832-2019)
}

\author{
ANTONIO ORIHUELA ${ }^{1 *} \&$ JOSÉ M. LÓPEZ-OSORIO ${ }^{2 \dagger}$ \\ ${ }^{1}$ Escuela de Estudios Árabes, CSIC, Spain \\ ${ }^{2}$ Universidad de Málaga, Spain
}

\begin{abstract}
The bath of the Walnut or Bañuelo (Hammām al-ŶYawa), in Granada (Spain), is one of the most notable and best-preserved buildings of its kind in the Iberian Peninsula, following the extensive conservation work directed by architect Leopoldo Torres-Balbás in 1927-1928. Traditionally, it has been dated to the 11th century, when a Taifa kingdom ruled by the Zirid dynasty, of Berber origin, was established in Granada. The recent restoration work carried out on it has prompted us to investigate the long process of study, characterization and valorisation of this important example of Andalusí architecture. The paper presents a broad critical analysis of this process of detailed discovery over almost two centuries (1832-2019), based on descriptions, photographs and plans. It starts with the first drawings made by the French artist J.-Ph. Girault de Prangey and finishes with the recent archaeological survey. During the discussion the authors give their own vision of the different hypotheses raised, assessing positive contributions of each of them. Finally, they propose a new hypothesis summing up the best ideas contributed by previous authors and correcting their errors or omissions. This new hypothesis is described and drawn in ground floor plans and cross-sections.

Keywords: Hammām al-Ŷawza, Bañuelo, El Nogal bath, Arab bath, Andalusí bath, Islamic Granada, conservation, historiography.
\end{abstract}

\section{INTRODUCTION}

The bath of the Walnut or Bañuelo (Hammām al-ŶYwza) is located in the present quarter of El Albaicín in Granada, beside the Puerta de los Tableros (Bāb al-Difāf), which connected the defensive lines of the Medina and the fortress of the Alhambra. This construction is one of the most representative examples of Andalusí baths in the Islamic West, due mainly to its good state of conservation and numerous restoration interventions since the late $1920 \mathrm{~s}$, when L. Torres-Balbás, the then architect-director of the Alhambra, began restoration work on this and other monuments in the city.

The building currently occupies a $380 \mathrm{~m}^{2}$ plot, following the characteristic floor plan of Andalusí baths which consisted of different interlinked rooms: relaxation room, changing room, cool room, warm room, and hot room. This last room housed the steam bath itself, on the hypocaust: an underground vaulted space directly linked with the furnace and the boiler. Beside it were the service quarter and wood store, located at the north end of the complex of El Bañuelo. This could be entered from the street to allow for service access, as well as for the supply of logs and other types of fuel. The public entrance was located at the south end, currently used for access, through a small two-storey building leading to an open courtyard, which must originally have been covered and used as a relaxation room.

The bath is mostly built with lime concrete walls and brick vaults, along with octagonal and star-shaped oculi to allow light in and to control the steam generated in the hot room

\footnotetext{
* ORCID: https://orcid.org/0000-0003-2443-552X

† ORCID: https://orcid.org/0000-0002-9545-0711
} 


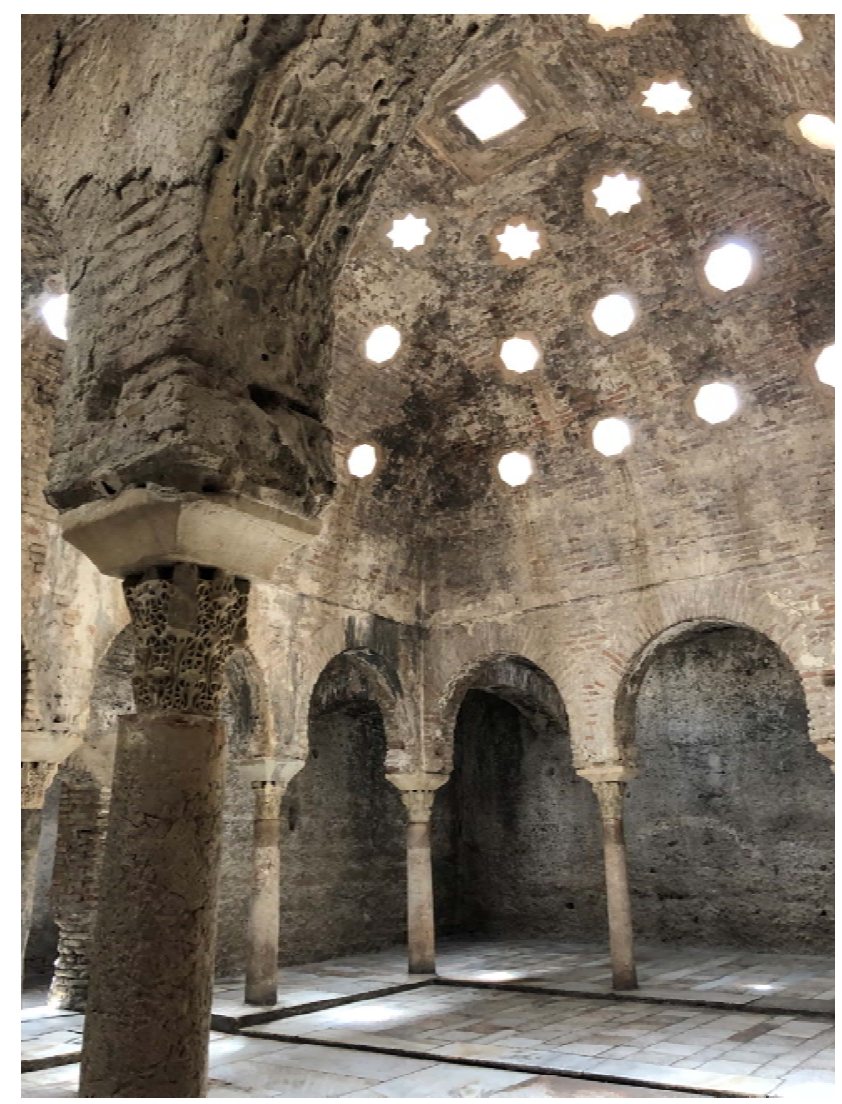

Figure 1: Warm room of El Bañuelo. (Photo: J.M. López-Osorio.)

(Fig. 1). Water was supplied from the north end, along a branch of the Axares irrigation channel, and ran out to the river Darro along a brick drain.

\section{HISTORICAL ANALYSIS}

We begin this study with a historical analysis in chronological order, focusing on authors who have worked on the revalorisation and recovery of the bath as a publicly owned monument. We are here concerned with authors who have made truly original contributions, either detailed descriptions of the bath or early images and plans. Therefore, this does not include authors of recent research studies with no documentary references or studies that simply summarise previously published texts. This selection highlights the importance of the first drawings published by Girault de Prangey, although the operation of the different bath spaces was not properly understood until the studies by Gómez-Moreno (González) and his son, Gómez-Moreno (Martínez). The later restoration work by Torres-Balbás was extremely important, as were the hypotheses on initial conditions developed in the School of Arabic Studies (CSIC) by Navarro-Palazón and Jiménez-Castillo and by Almagro-Gorbea. In another study, currently in press, we provide a critical analysis of a dozen restoration and conservation interventions by eight different specialists or specialist teams over the last century. 
1837. Joseph-Philibert Girault de Prangey (1804-1892) was a French artist and early researcher into Islamic architecture on both sides of the Mediterranean, who later used daguerreotypes to document historic buildings. He carried out surveys and made on-site drawings in 1832-1833, publishing them as engravings in Paris in 1837 under the title Monuments Arabes et Moresques de Cordoue, Seville et Grenade. Souvenirs de Grenade et de l'Alhambra [1]. His work included a detailed plan of El Bañuelo, surprisingly included in a plate of cross-sections, elevations and details of the palaces of the Alhambra (Planche 30) (Fig. 2). The engraving does not appear to show the condition of the building at that point, but rather seems an attempt to show hypothetical initial conditions, as it does not include the laundry located in the original warm room, which had been added once it was no longer used as a bath. On the ground floor plan it is worth highlighting the outline of the entrance area, which is made up of the access, the relaxation room and latrines, spaces which had perhaps not yet been as significantly transformed by residential constructions as in the plans and photographs of the first quarter of the 20th century. A symmetrical structure and porticos on pillars can be seen on the north and south sides of the relaxation room, providing an initial hypothesis of its original condition, ignored by later historians. Failing to draw the columns of the double arch delimiting the west alcove of the hot room may well have been an error.

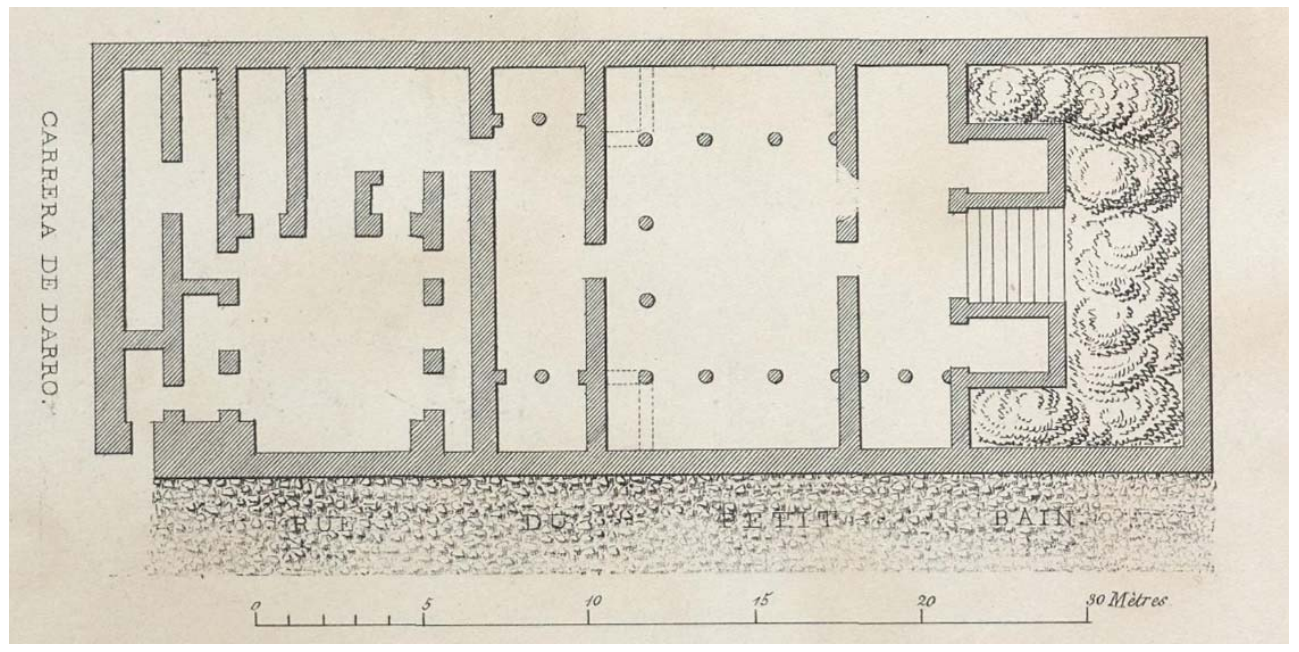

Figure 2: Ground floor plan of El Bañuelo [1].

The most detailed engraving, entitled "Anciens Bains Moresques Ruinés" (Planche 11) (Fig. 3), shows a view of the warm room taken from the west side. A public laundry can be seen in the middle alongside an interior pool. The accompanying text provides a brief description of the use of the building, although it is somewhat inaccurate and interprets the hot room as the relaxation room and the service quarters as the garden. This may have been due to the thick vegetation which apparently grew on the rubble from the collapsed vault. One of the most important contributions of the engraving is that it shows the wall separating the warm and hot rooms, with a large round arch to the left of the connecting door. This opening may have been designed to widen one of the original conduits of one of the hypocaust chimneys, which was probably damaged. This opening, which also appears on the floor plan described above, shows it as a break, providing a glimpse of the modern staircase 


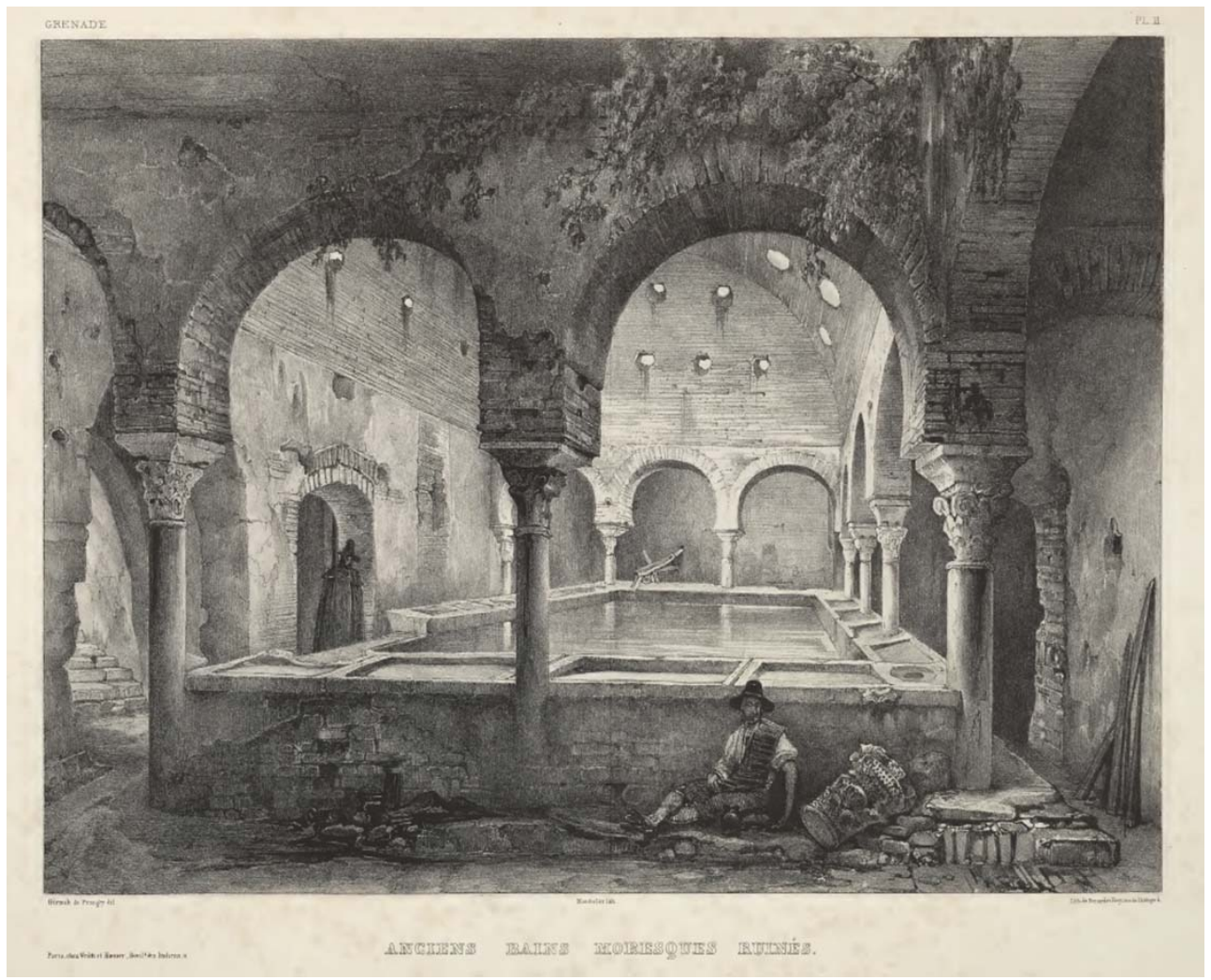

Figure 3: Warm room of El Bañuelo [1].

occupying the space of the former hot water tank and connecting the hot room to the wood store above. Another detail to note in the engraving is the wooden gutter supplying water to the pool from a hole in the east wall of the room. This water supply point can still be seen today in the form of slightly overhanging brick and is especially interesting as it shows that water was supplied to the bath from this side of the present Calle del Bañuelo. A break can also be observed in the southern section of the vault of the west portico. Furthermore, in addition to different details of the Alhambra, engraving number 22 also shows two capitals from the warm room, one of which features Arabic inscriptions in the abacus. Remains of these inscriptions are still found on the capital of one of the columns of the south gallery of the warm room, to the right of the entrance from the cool room.

"PLANCHE XI. BAINS MORESQUES RUINÉS. Salle principale d'un édifice presque complétement détruit, mais dont la désignation ne peut être doutese, car l'on y retrouve encore tout ce qui constitue un Bain Moresque de nos jours : une cour d'entrée avec chambres autour, une première salle, puis une autre plus grande (celle dessinée), puis une troisième avec estrades, lits de repos, se terminant par un jardin. (Voir le plan général de ces Bains, pl. 30) C'est encore là une copie exacte des Bains antiques dans leur ensemble et dans tous leurs détails. Les chapiteaux des colonnes de cette salle sont fort curieux et remontent peut-être aux Xe ou XIe siècles. Les caractères Koufiques très anciens que conserve l'un d'eux attestent leur origine et leur époque (Voir pl. 22.)" [1]. 
Girault de Prangey's ground-breaking graphic contribution on the subject of El Bañuelo was far superior to the brief description accompanying the individual engravings, as the author had previously been unable to interpret the functions of the rooms in the north section of the building, where the hot room, the boiler and wood store were located. However, he dated the capitals of the warm room quite accurately. In later works he used this to date the construction of the building to the 10th-11th centuries and establish a historical tradition which is still encountered today. At the same time the author stated that the terms More and Moresque, in his books unfortunately refer to the Arab-Maghribi who conquered most of the Iberian Peninsula from the late 11th century onwards, bringing about major changes in the architecture of al-Andalus [2]. Therefore, these terms must not be confused with those of Moor or Morisco as currently understood.

1846. José Giménez-Serrano (1821-1859) was a journalist and writer and - in his later years - a professor in commercial law. Giménez-Serrano revealed that "there is a dirty and foul-smelling house, now a pigsty and laundry where Arab baths are located...". He also stated that at the time the entrance courtyard was untouched and the remains of the square Macael marble pool could be seen in the centre. The warm room is described as "the covered courtyard of the cold water tank", suggesting that he considered the pool of the laundry found there in the 19th century to be an original element of the Andalusí bath. His misinterpretation of the rooms of the bath concludes by stating that "opposite is the hot room leading to the gardens, full of fruit trees, African palms and bay trees" [3]. He therefore agrees with Girault de Prangey's opinion, viewing the vegetation growing on the rubble of the collapsed wood store as part of the original garden.

1878. Rafael Contreras-Muñoz (1826-1890) was an adornist restorer of the Alhambra who came from a long line of architects and restorers in Granada. He published a ground floor plan of El Bañuelo, as well as an small engraving of the warm room, although both plates were printed in reverse [4] (Fig. 4). Both were clearly inspired by those published by Girault de Prangey in 1837, although Contreras's ground plan shows the dimensions of the different spaces more accurately. This is especially apparent both in the entrance courtyard, with its square pool, further supporting the hypothesis of its symmetrical tracery, and in the south bay, with the façade overlooking the Carrera del Darro where the staircase to the upper floor was located. It is not devoid of errors, most importantly the omission of the columns of the south portico of the warm room. Furthermore, the description of the building was completely mistaken in assuming that it was accessed through the wood store and boiler area: "ARAB BATHS OF CARRERA DE DARRO - Today these are a modest house accessed via a square courtyard, around which the wall distribution of these buildings can still be

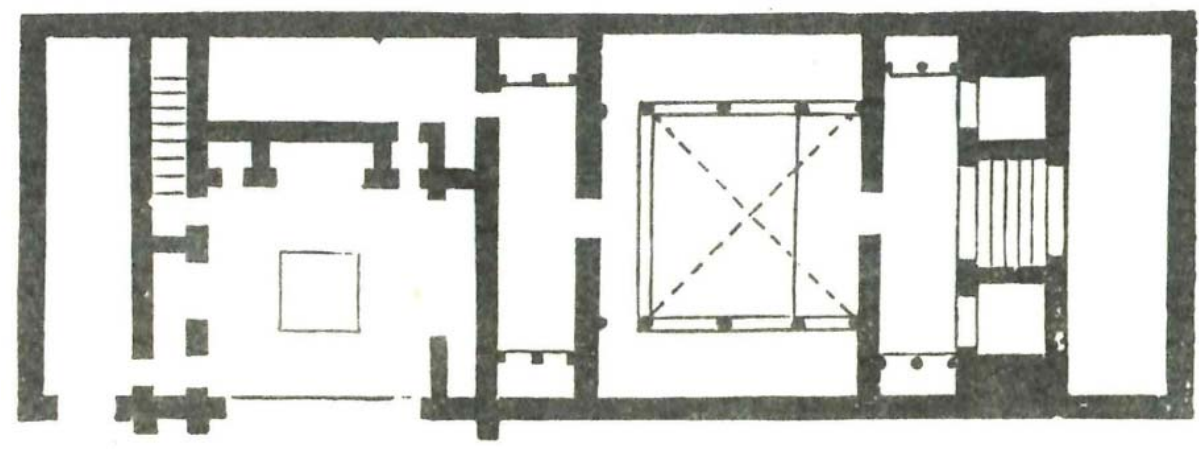

Figure 4: Ground floor plan of El Bañuelo [4]. 
observed. Beyond this courtyard, with a pool or pond in the middle, we find the most complete distribution of a public bathhouse. We assume that the entrance was located in the last room, a vaulted and now collapsed parallelogram. A wide staircase leads down to another long room with two alhamíes (alcoves) for relaxation at either end. Here there are two private bathing rooms, with a narrow door leading to a large bath for washing, whose walls are perfectly recognisable from the remaining colour and Arab design on lime plaster. After the central room with its vaults, skylights and air vents we access the room with the two alhamíes, very similar to the first one, and from there we enter other small rooms connected with the entrance house, a usual feature in these establishments" [4].

However, the description by Contreras includes interesting contributions such as stating that the wood store ("the last room") was originally vaulted and noting that the warm room included remains of a painted mural.

1886-1993. Antonio Almagro-Cárdenas (1856-1919) was a professor of Arabic and Hebrew in the Universities of Granada and Seville respectively. His collection of studies in instalments, Museo Granadino de Antigüedades Árabes, published between 1886 and 1993, dedicated a chapter to Arab Baths, written around 1889 [5]. Describing El Bañuelo he stated that at the time the entrance was through a residence, that the central room had been a public laundry until recently and that the semicylindrical vaults of the three perimeter galleries were mostly in a state of collapse. Aiming to offer a detailed description and recreation of the functions of the different rooms, he repeated the same mistakes as previous authors. However, he made accurate use of the term alhanía when referring to the spaces or alcoves at the end of the rectangular rooms. His most important contribution as an scholar in Arabic was probably the translation of the incomplete Kufic epigraphical inscription on one of the capitals of the bath's warm room, previously drawn by Girault de Prangey: "In the name of clement and merciful God. There is no power but in sublime God. Happiness and wellbeing can only be conserved through cleanliness" [5].

1889. Manuel Gómez-Moreno (Martínez) (1870-1970). The Sección de Excursiones del Centro Artístico de Granada visited El Bañuelo on 13.10.1889, publishing a description of it in its Boletín [6]. This description is likely to have been provided by the younger GómezMoreno (Martínez), who during his long life became a renowned professor in Arabic archaeology and member of three prestigious Academies. This was the first instance in which the architectural elements and constructive materials were described with archaeological precision. This brief account focused on the arches of the warm room "supported by Roman columns with different capitals, some Roman, some Visigoth and the remaining early Islamic, all of them with Corinthian and composite order". He also stressed the need to conserve the remains of the paintings adorning this room, in view of their unique importance. He lamented the state of ruin of the building, which he considered the most important existing in Granada from the "first period of Islamic architecture", as "its vaults let water through the cracks, threatening to collapse; some of the walls are starting to collapse; there are several rooms covered by earth and the floor is full of rubble".

1892. Manuel Gómez-Moreno (González) (1834-1918) was an excellent painter, archaeologist and art historian from Granada. In his Guía de Granada [7] he provided a detailed description of the bath, known as of El Chauze (of the Walnut) in 1494 and a few years later as the Bath of Palacios or the Gate of Guadix. This description followed the logical order of its use as an Andalusí bath with scientific precision, although it did not state the function of individual rooms: "The small courtyard is reached through a small modern house. The courtyard's west wall still preserves remains of the opening or small recesses, with a high horseshoe arch, which was perhaps occupied by the caretaker of the establishment". He stressed the poor condition of the cold room, half of which was used as a modern cistern, and 
the loss of the columns of the rooms at the ends. He stated that the ten columns in the warm room "were reused from previous buildings, have no bases and have shafts in Loja marble; one of the capitals is Roman, in the Corinthian style, and the others must have been made during the early Islamic rule, combining the Corinthian and composite orders". In the notes that complete the second edition of his work, he dates their execution to the 10th century [7]. He also highlighted the three imitation arches painted on the north wall of this room and the pool in the middle of the laundry, which some had mistakenly thought was part of the original construction. The northernmost quarters, which were full of rubble, had been used as a furnace and wood store, and it was still possible to see the springing of the missing "arched vault" of the wood store or service quarters. Finally, he identified the existence of a "wall made up of stone slabs and brick in alternating courses, as in some Byzantine buildings", which is still preserved in the east wall of the hot room.

The small plan accompanying the text shows the bath without later additions. Only the west bay is drawn in the entrance area, as the rest would have been hidden by the small dwelling built around 1880. It reflects only two chimneys in the hypocaust, set in the wall separating the hot and warm rooms. A dotted line drawn in an east-west direction represents a hypothetical missing wall, which can now be said to never have existed, as well as another in the east wall of this space, in the place where the access for employees and supply fuel from the current Calle del Bañuelo must have been. Based on the antiquity of all its architectural details Gómez-Moreno (González) dated it to the 11th century, "as the oldest building existing in Granada, with the exception of fortresses and towers". This dating, coinciding with that previously suggested by Girault de Prangey, was accepted by later historians until it was recently questioned in the early 21 st century.

In 1901 he drafted a report on El Bañuelo for the Monuments Commission of the Province of Granada to promote the building's acquisition by the state, as this was the only way to save it from ruin [8].

1906. Mariano Gaspar-Remiro (1868-1925), a professor of Hebrew in the University of Salamanca and later of Arabic in Granada, edited and translated an Arabic notarial document from the beginning of the month of muharram in the year 852 of the Hegira, corresponding to the month of March of the year 1448 [9]. This document mentions the existence of the Baño de la ruina o del Axautar, which belonged to the public Treasury (Bayt al-mal). This was acquired from the sultan Muhammad, who may have been the ninth of this name in the Nasrid dynasty, known as al-Aysar (the left-handed), according to recent chronological research on the rulers of the mid-15th century [10]. However, forty years later, Luis Seco de Lucena-Paredes (1901-1974) confirmed that this bath was beside the main mosque and had no connection to the Hammām al Ŷawza or Bath of the Walnut, commonly known as El Bañuelo [11].

1907. Manuel Gómez-Moreno (Martínez), again in his unfinished work Monumentos arquitectónicos de la provincia de Granada, republished in 1949, when detailing the Roman materials reused in Islamic buildings, highlighted the capital installed in El Bañuelo in the 11th century: "a very beautiful capital in the Corinthian style, with simple scrolls of leaves and ornate carving in the centre" [12].

1912. Gonzalo Enríquez de Luna-Enríquez, a military officer interested in collecting and archaeology, and spousal co-owner of El Bañuelo [13], requested a municipal permit to remove the rubble from the bath, as half the columns were covered by rubble over a metre high [14].

1913. Francisco de Paula Valladar-Serrano (1852-1924), journalist, writer, academic and expert on local artistic heritage, drew up the report for the Provincial Commission of Historic and Artistic Monuments of Granada requesting that El Bañuelo be declared a National 
Monument and acquired by the state. He also mentioned that excavation work carried out by the owners had uncovered over a metre of columns, which had been half-buried to transform the warm room into a public laundry [15].

1916. José Ramón Mélida-Alinari (1856-1933), archaeologist and scholar, drafted the mandatory Report of the Royal Academy of History, of 10 March 1916, supporting its declaration as a National Monument and the purchase by the state of El Bañuelo. He dated it to the 11th or 12th centuries based on its artistic features [16].

1918. Vicente Lampérez-Romea (1861-1923) was a restoration architect, professor, architecture historian and academic. He drafted the "Report on the file relating to the building called 'El Bañuelo', in Granada" as a rapporteur of the Central Monuments Commission at the Royal Academy of Fine Arts of San Fernando. He noted the inclusion in the file of a plan of the building and some photographs requested from the owner in June 1916. In his opinion, "Based on the constructive details, the shape of the arches and the style of the capitals, the construction of El Bañuelo dates to the 11th or 12th century". Lampérez-Romea also felt that the state ought to purchase the building and declare it a National Monument [17].

1918. Declaration as a National Monument on 30 November 1918 (Gaceta de Madrid, issue 338, of 4 December 1918), at the request of its owner D. Gonzalo Enríquez de Luna, this status was granted five and a half years after the Provincial Commission of Historic and Artistic Monuments of Granada requested it.

1919. Fernando Wilhelmi-Manzano (1880-1969) was an architect for the Diputación de Granada who worked as an assistant architect at the Alhambra. He drew up the plan of the ground floor, dated 22 May 1919 (APAG P-001155) (Fig. 5), before submitting the Certificate of examination and appraisal to the Royal Academy of Fine Arts of San Fernando. The plan included the residential unit in the entrance area, as well as the cistern, which at that point occupied the eastern third of the cool room. The service quarters at the north end are not drawn but listed as "debris fill".

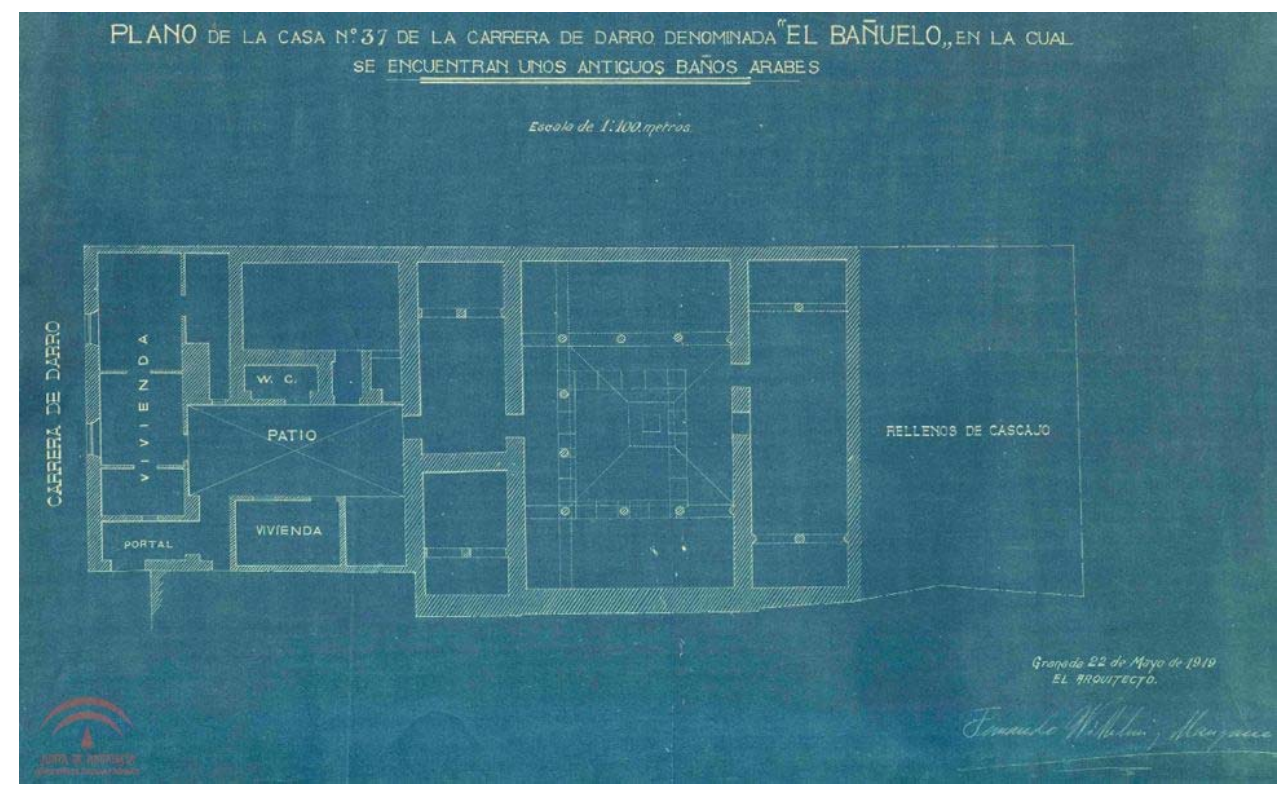

Figure 5: Ground floor plan of El Bañuelo. (Source: F. Wilhemi-Manzano, 1919, APAG P-001155.) 
1921 Manuel Zabala-Gallardo (1853-1934) was an architect, professor and scholar. He drew up the mandatory "Report on the certification of examination and appraisal of the house known as 'El Bañuelo' (Granada)", dated 11 March 1921, as a rapporteur of the Architecture Department of the Royal Academy of Fine Arts of San Fernando. He noted that part of the site was dedicated to modest homes and another uninhabited area, which was made up of almost the entirety of the former bath, even the debris-filled backyard. The Academy approved the architect Wilhelmi's refusal of the owner's request to conserve ownership of part of the building and accepted the proposed appraisal of the entire site for $16,540.30$ pts [18].

1927-1928. Leopoldo Torres-Balbás (1888-1960) was the architect-director of the Alhambra from 1923 until 1936. In December 1927, he drew up an extremely precise plan for the Project for the Repairs of El Bañuelo [19] (Fig. 6). The work was carried out with minimum intervention and making great savings, carefully executed, avoiding the introduction of unnecessary elements to ensure that the building did not lose what he called "its appearance of mediaeval construction". The construction plans show the ground surveys, with the remains of the original flooring, as well as underground ones showing the general drain throughout the building with a tracery near its west walls, which ran off into the river Darro (Figs 7 and 8). Torres-Balbás also documented the original walls found beneath the flooring of the south bay of the current entrance courtyard.

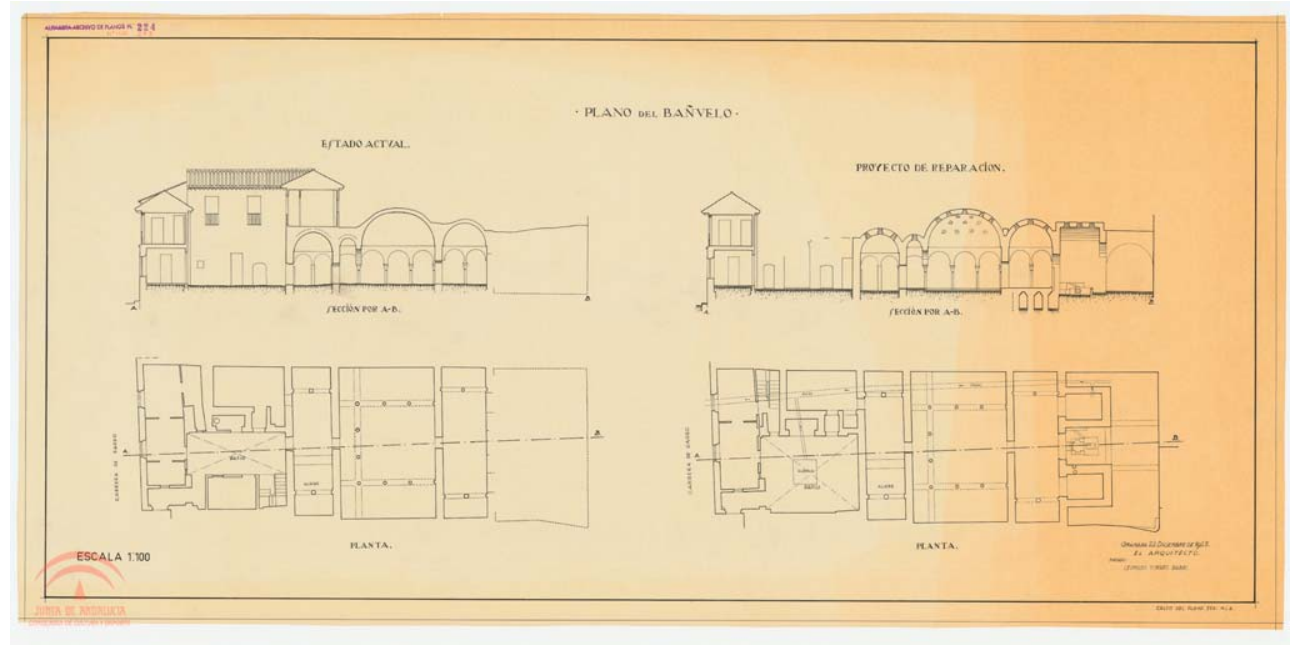

Figure 6: Project for the repairs of El Bañuelo: Ground floor plan and cross-section, before and after the intervention [19].

Following completion of the work in April 1928, he published a short piece in Reflejos magazine: "Acquired with the income of the Alhambra, El Bañuelo, an interesting Arab bath from the 11th century, situated on Carrera del Darro, was completely repaired at the end of the month of March, saving it definitively from what seemed like almost certain destruction" [20].

1951. Manuel Gómez-Moreno (Martínez) once again produced a detailed description of El Bañuelo, complete with ground floor and cross-section plans (Fig. 9). These one were based on the graphic documents prepared by Torres-Balbás at a 1:50 scale during the 


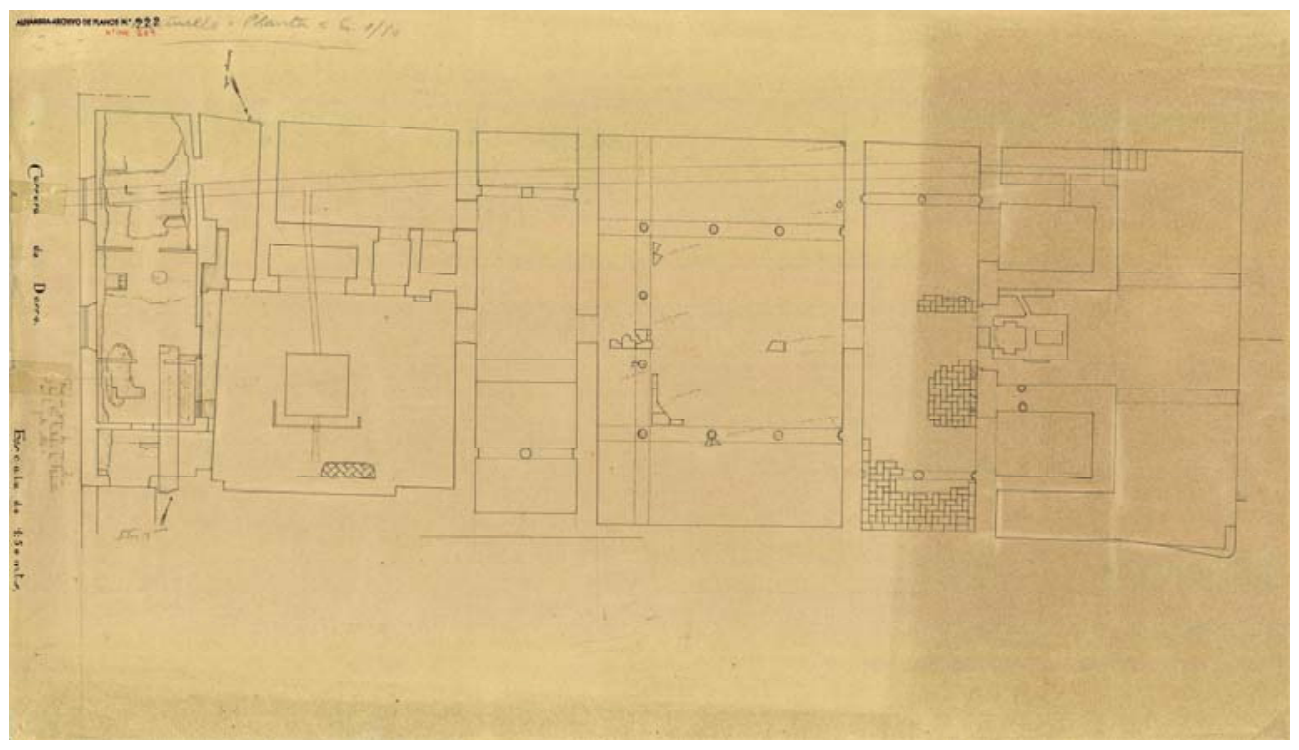

Figure 7: Ground floor plan of El Bañuelo with archaeological details. (Source: L. TorresBalbás, 1928, APAG P-000269.)

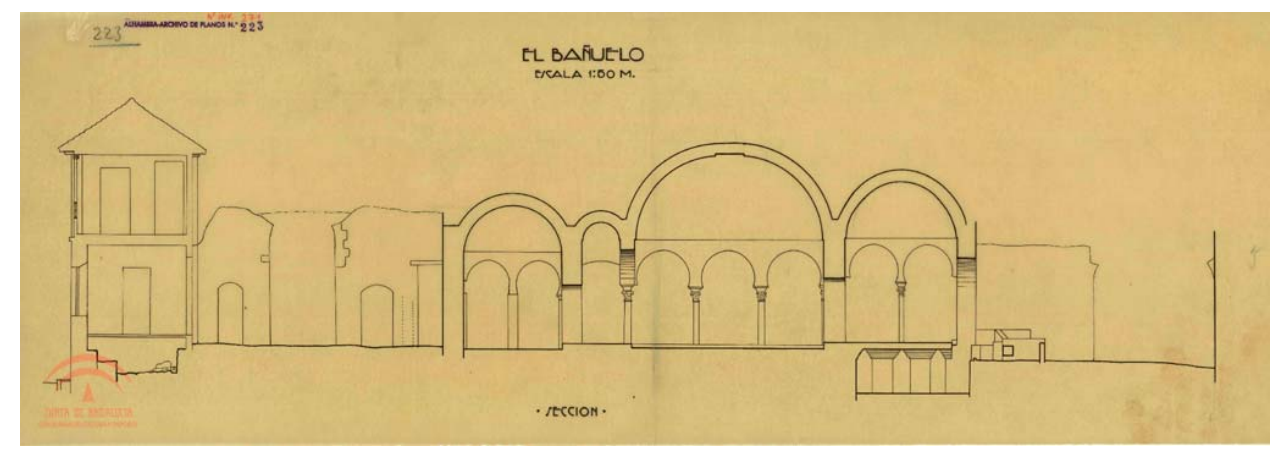

Figure 8: Cross-section of El Bañuelo with archaeological details. (Source: L. TorresBalbás, 1928, APAG P-000271.)

construction work in 1928 (APAG P-000269 and APAG P-000271) (Figs 7 and 8), as well as a drawing of a capital of the warm water room and four good photographs. Of these, the photograph of the hot room predates the completion of this project, as the floor of this room is covered in rubble and the oculi or luminaries of the vault had not yet been established as stars or octagons. The plan features several steps adjoining the west wall of the service area, as had been drawn by Torres-Balbás. For the first time the cross-section shows the chimneys in the wall separating the hot and warm rooms, as well as the remains of the vault, which covered the wood store. As regards the dating of the capitals of previous works GómezMoreno (Martínez) holds that: "the capitals include a Roman one in the Corinthian style; except for two others, one of them inscribed with simple eulogies, which were caliphal and 


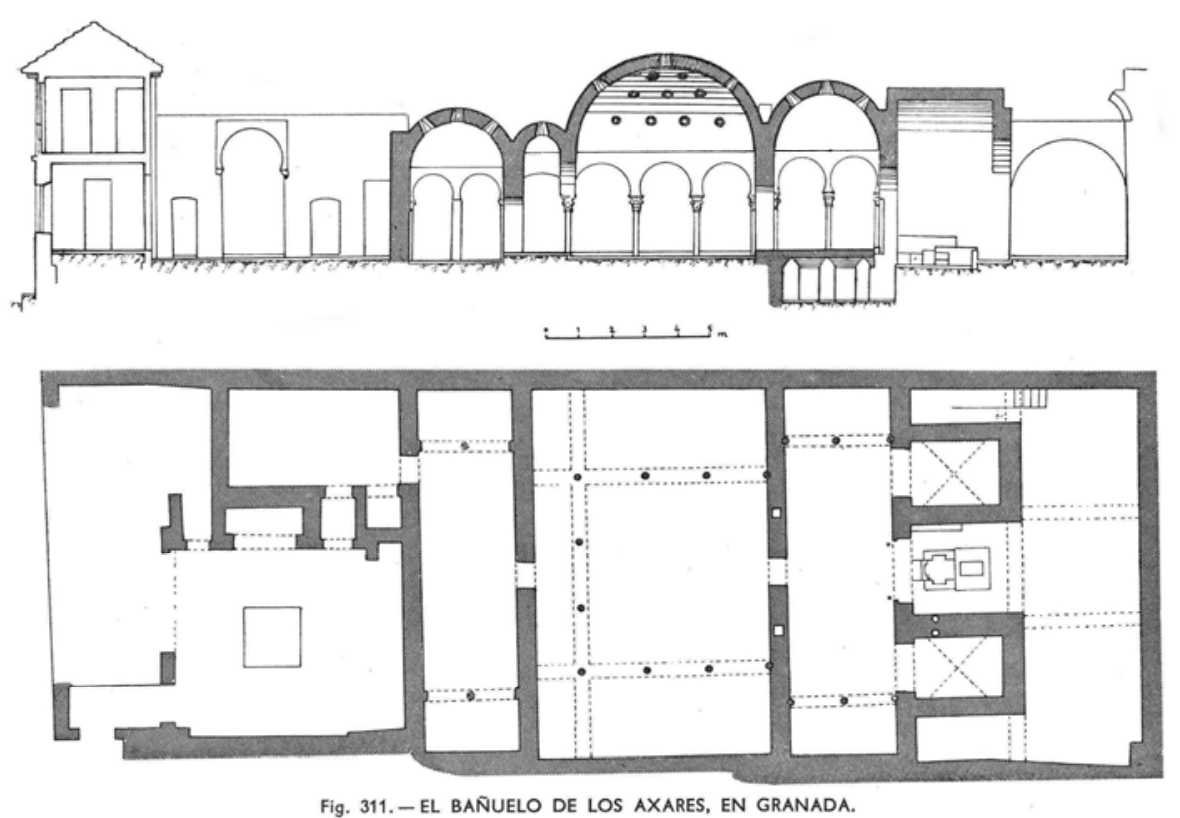

Figure 9: Ground floor plan and cross-section of El Bañuelo [21].

reused; they only appear to be contemporary to the bath, and definitely date from the 11 th century, a Corinthian one with two lines of quite ornate roughly carved leaves, and another of composite order with almost no volutes" [21].

2012. Julio Navarro-Palazón and Pedro Jiménez-Castillo, archaeologist-researchers from the School of Arabic Studies (CSIC), studied the bath and its urban surroundings with innovative proposals. According to them the entrance was in the southeast corner of the plot when accessed from Carrera del Darro, a street they thought was of mediaeval origin but had been widened in modern times to the detriment of the south bay of the bath. They also held that the space between the eastern limit of El Bañuelo and the street of the same name was filled by a bay of shops. As regards the distribution, they suggest the presence of a relaxation room or changing room covered with a wooden framework rather than the current entrance courtyard. They also analysed traces of the access to the wood store from the street of El Bañuelo, through a plot which was not initially purchased by the state. They dated the bath to a later date than historians had traditionally done, "as its concrete wall constructions and the abundant use of brick in vaults to form buttresses and reinforcements in openings are characteristic of a later architecture, from the 12th century at least" [22].

2014. Antonio Almagro-Gorbea, architect-researcher from the School of Arabic Studies (CSIC) reiterates what he had already suggested ten years previously, that the current access courtyard used to be a room with a collar-beam roof [23]. To do so he published ground floor plans and cross-sections of the current condition and of the initial hypothetical conditions (Fig. 10). In the relaxation room he proposes two porticos with three openings over columns on the north and south sides following the drawings by Girault de Prangey. These may have been partly conserved at the time of his visit in 1832-1833, although Girault de Prangey had drawn rectangular pillars instead of columns. However, he identified differences with the innovative urbanistic proposals of Navarro and Jiménez, as he held that the original entrance 

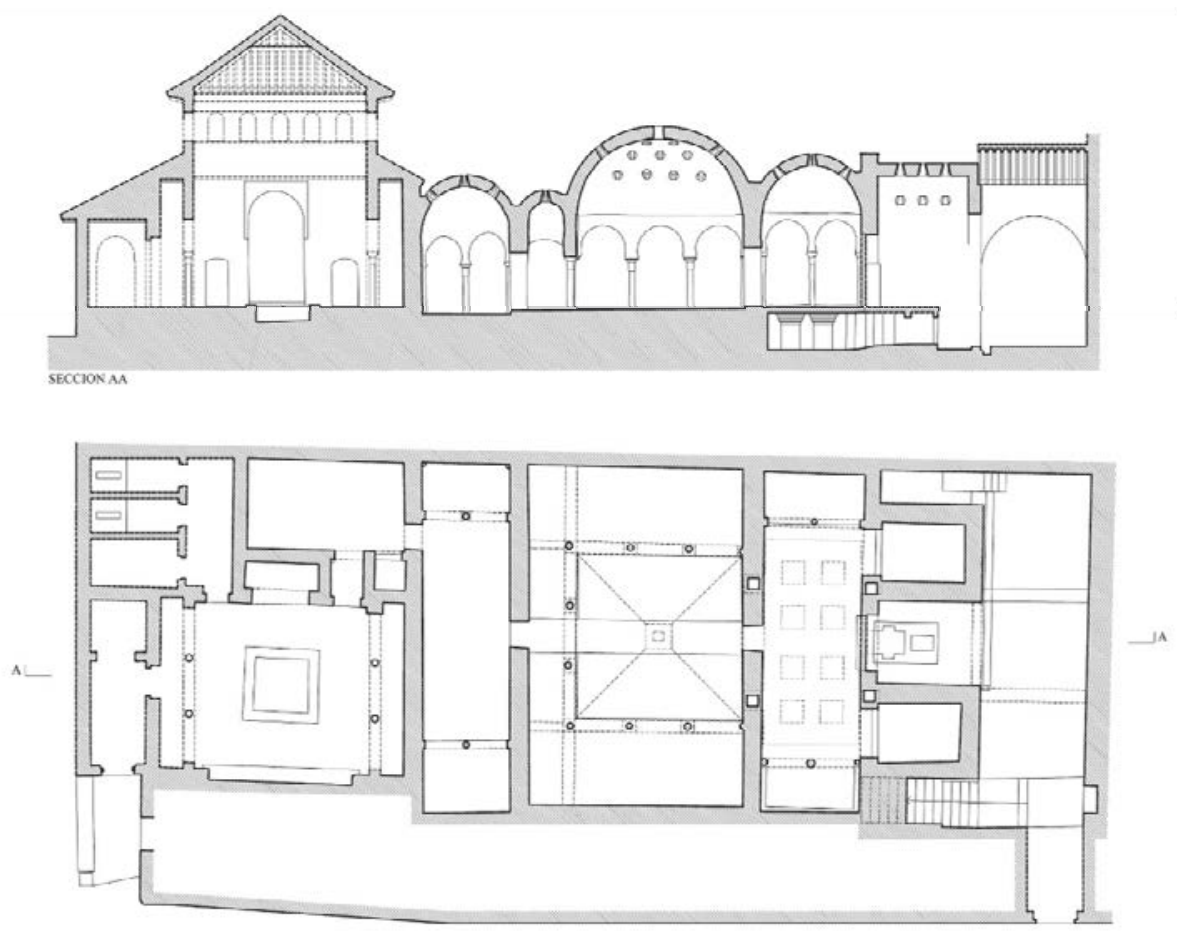

Figure 10: Hypothetical original ground floor plan and cross-section of El Bañuelo [24].

coincided with the current one, given that the Carrera del Darro did not exist in the Nasrid era and the buildings of this block overlooked the river Darro directly, as is the case on the left bank. He assumed that the wood store was covered by a wooden structure supported by two dividing transverse arches and was lower than now, on a level with the hypocaust, to aid in stocking the hearth and cleaning the embers. He considered that all the existing capitals, including those thought to be from the 11th century would have been reused at a later date as "the typology of the bath, which we consider highly evolved and similar to those of the Nasrid era suggested a much later date" [24].

\section{CONCLUSIONS}

Critical analysis of the history and in-depth research of the building over many years allow us to provide a reasoned proposal on the initial condition of the Bath of the Walnut or Bañuelo. This proposal is similar to that published by Almagro-Gorbea, although it introduces some important corrections and nuances (Fig. 11).

In the entrance area our proposal is similar to the above, except for one small hypothetical difference, the presence of pillars instead of columns in the north and south side porticos, as 


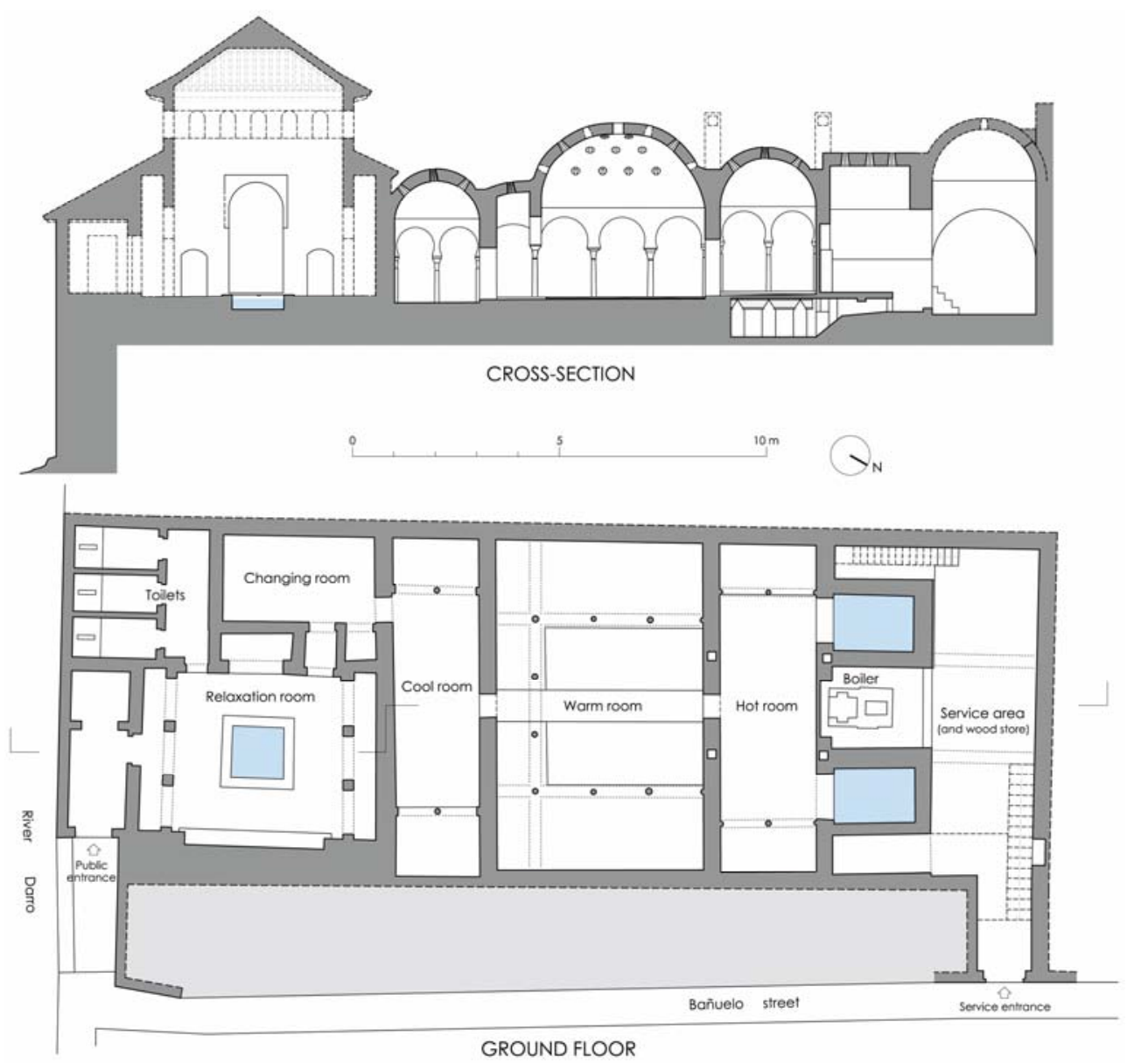

Figure 11: Hypothetical original ground floor plan and cross-section of El Bañuelo. (Source: A. Orihuela and J.M. López-Osorio, 2019.)

drawn by Girault de Prangey [1]. The only differences we propose for the wet area of the bath lie in the hot room, specifically the pilasters at the end of the west alhanía, added following the construction work of 1995 [25]. Prior to this there had been columns semiembedded in the walls, as in the east alhanía. The chimneys of the hypocaust are drawn on the ground floor plan and the cross-section, although, at least since the work of TorresBalbás, there are only traces of the top of the two chimneys in the south wall of the hot room.

In the service quarters the wood store incorporated a half-barrel vault, whose imprints and part of the bricks of the springing in the Bañuelo northern wall are still visible (Fig. 12). The wood store is reinforced with two arch buttresses below the vault to reinforce the supporting walls. Although Torres-Balbás identified the existence of this original vault, he did not feel its reconstruction was necessary in the work of 1927-1928 [19]. In addition, the three bottom steps of a small staircase and traces of the rest of the stairs are also observed on the west wall of the wood store. This staircase, which is only $65 \mathrm{~cm}$ wide, led to the vaults from the service quarters although its construction may not have been completed. A small brick barrel vault 


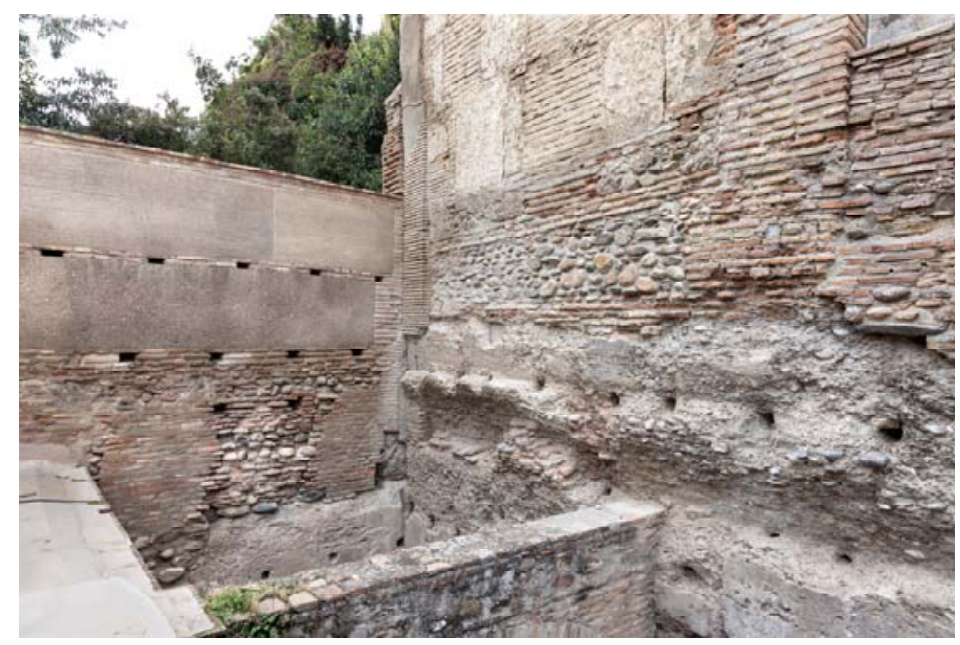

Figure 12: Current situation of the Service area of El Bañuelo, looking towards the Northwest. The remains of the fallen vault are still visible. (Photo: C. GarcíaZarza.)

rebuilt above it by Torres-Balbás now blocks access to the vaults from this point. His construction work incorporated a modern access to the vaults from the terrace of the caretaker's home, in the south end of the complex. Furthermore, in his 1994-1995 intervention, Rodríguez-Sáez built a wide staircase at the east end of the wood store, which was not based on conclusive archaeological remains. Finally, we assume that there was a staircase there from Calle Bañuelo down to the service quarters, with a difference in levels of around $3.50 \mathrm{~m}$.

\section{ACKNOWLEDGEMENT}

We thank Mr. Nadil Chilah and Mr. Afelio Navarro for giving us a copy of the document Archivo Municipal de Granada, Leg. 2283, pieza 30. Negociado de Fomento, año 1912 (8 de noviembre), exp. 36 .

\section{REFERENCES}

[1] Girault de Prangey, J.-Ph., Monuments Arabes et Moresques de Cordoue, Seville et Grenade. Souvenirs de Grenade et de l'Alhambra, Chez Veith \& Hauser: Paris, 1837. (1st ed. in Spanish, Recuerdos de Granada y de la Alhambra, Ed. Escudo de Oro: Barcelona, 1982.)

[2] Girault de Prangey, J.-Ph., Essai sur l'Architecture des Arabes et des Mores en Espagne, en Silicie et en Barbarie, A. Hauser: Paris, pp. 57-58, 68-69, 205, 1841.

[3] Giménez-Serrano, J., Manual del Artista y del Viagero (sic) en Granada, 2nd ed., J.A. Linares: Granada, pp. 343-344, 1846.

[4] Contreras, R., Estudio descriptivo de los Monumentos Árabes de Granada, Sevilla y Córdoba, 2nd ed., Imprenta y Litografía de A. Rodero: Madrid, pp. 348-349, 1878.

[5] Almagro-Cárdenas, A., Museo Granadino de Antigüedades Árabes: Colección de Estudios Arqueológicos sobre los Monumentos Árabes de Granada que hoy se conservan en poder de particulares y datos de otros que ya han desaparecido, Imprenta de la Lealtad: Granada, pp. 83-86, 1886-1993. 
[6] Gómez-Moreno (Martínez), M., Boletín del Centro Artístico de Granada, Sección de Excursiones, 74, p. 9, 16 Oct.1889.

[7] Gómez-Moreno (González), M., Guía de Granada, Imprenta I. Ventura: Granada, pp. 415-418, 1892. (2nd ed. facsímil, Universidad de Granada, Instituto Gómez-Moreno de la Fundación Rodríguez-Acosta, II vol., 1982.)

[8] Gómez-Moreno (González), M., "El Bañuelo" (1901). Obra dispersa e inédita, Compilación y Estudio Preliminar de Javier Moya Morales, ed. M. Gómez-Moreno González. Instituto Gómez-Moreno, Fundación Rodríguez-Acosta: Granada, p. 636, 2004.

[9] Gaspar-Remiro, M., De Granada musulmana. El Baño de la ruina o del Axautar. Boletín de la Real Academia de la Historia, 48(1), pp. 43-53. 1906. Also published in La Alhambra, 9, pp. 98-101, 123-125, 146-150, 1906.

[10] Vidal-Castro, F., Historia Política. Historia de España Menéndez Pidal, Tomo VIII (3). El reino Nazarí de Granada (1232-1492). Espasa-Calpe: Madrid, pp. 47-248, 2000.

[11] Seco de Lucena-Paredes, L., El baño de Šawțar en Granada. Al-Andalus, 12(1), pp. 211-213, 1947.

[12] Gómez-Moreno (Martínez) M., Monumentos arquitectónicos de la provincia de Granada (1907). 2nd ed., Separata de Misceláneas, historia, arte-arqueología, por Manuel Gómez-Moreno. Instituto Diego Velázquez: Madrid, pp. 347-390, 1949.

[13] Pozo-Felguera, G., Los hombres que salvaron el Bañuelo milenario. El Independiente de Granada, 18 Nov. 2018. www.elindependientedegranada.es/cultura/hombres-quesalvaron-banuelo-ilenario\#disqus thread. Accessed on: 19 Nov. 2018.

[14] Archivo Municipal de Granada, Lèg. 2283, pieza 30. Negociado de Fomento, año 1912 (8 de noviembre), exp. 36.

[15] Valladar-Serrano, F. de P., El Bañuelo o Baño del Puente del Cadí, La Alhambra. Revista quincenal de Artes y Letras, año XVI, 366, pp. 241-245, 1913.

[16] Mélida-Alinari, J.R., El Bañuelo. Baños Árabes subsistentes en Granada. Boletín de la Real Academia de la Historia, 68, pp. 503-506, 1916.

[17] Lampérez-Romea, V., Informe sobre el expediente relativo al edificio llamado "El Bañuelo", en Granada. Boletín de la R.A.B.A.S.F., 48, pp. 224-228, 1918.

[18] Zabala-Gallardo, M., Informe sobre certificado de reconocimiento y tasación de la casa denominada "El Bañuelo" (Granada). Boletín de la R.A.B.A.S.F., 59, pp. 117-118, 1921.

[19] Torres-Balbás, L., Proyecto de reparación del Bañuelo, Granada, Dec. 1927. Ministerio de Instrucción Pública y Bellas Artes (APAG, Leg. 2005/004).

[20] Torres-Balbás, L., Los monumentos de Granada en 1928. Revista Reflejos, Apr., pp. 57-59, 1928.

[21] Gómez-Moreno (Martínez), M., Ars Hispaniae. Historia universal del arte hispánico. Vol. III: El arte árabe español hasta los almohades. Arte mozárabe/por Manuel GómezMoreno, Editorial Plus-Ultra: Madrid, pp. 257-261, 1951.

[22] Navarro-Palazón, J. \& Jiménez-Castillo, P., El Bañuelo de Granada en su contexto arquitectónico y urbanístico. El legado andalusí, 45, pp. 1-9, 2012.

[23] Almagro-Gorbea, A., Levantamiento arquitectónico, EUG: Granada, pp. 111-116, 2004.

[24] Almagro-Gorbea, A., Una hipótesis sobre la forma original del Bañuelo de Granada. Diálogos de Arte. Homenaje al profesor Domingo Sánchez-Mesa Martín, eds D. Sánchez-Mesa Martínez \& J.J. López-Guadalupe, EUG: Granada, pp. 89-94, 2014.

[25] Rodríguez-Sáez, R., Restauración de los Baños Árabes del Bañuelo, Granada, Consejería de Cultura, Junta de Andalucía (BC. 01161/94). Feb. 1993. 